\title{
Carsten Friberg
}

\section{Videnssamfundet og viden}

Vi lever i et videnssamfund. I hvert fald hvis det står til troende, hvad der høres i den offentlige debat. Vi lever også i andre samfund, fx i informationssamfundet, risikosamfundet og fritidssamfundet, måske også i oplevelsessamfundet, selv om det ikke rigtig er slået igennem at kalde det sådan. Vi har ganske vist en oplevelsesøkonomi, men et årti før vi fik den, foreslog den tyske sociolog Gerhard Schulze oplevelsessamfundet (se Schulze 1992). Måske er der her en parallel til videnssamfundet. Vi har en vidensøkonomi, men har vi nu også et videnssamfund? Det spørgsmål skal det følgende kredse om ved først og fremmest at overveje, hvad det er for en viden, der er og kan være tale om.

Vores samfund skifter konstant navn, så måske haster det lidt med at give en kommentar til videnssamfundet, inden det er erstattet af en anden overskrift. Egentlig må man nok som det første overveje, om det dækker noget reelt, eller om det snarere er en overskrift, der har en funktion i primært politiske sammenhænge. Filosofisk kan man sige, at det nok er et navn for noget, men det er ikke også et begreb, det vil sige, det dækker over nogle forestillinger, som i dette tilfælde nok især er bundet til politiske dagsordener, men der hører ingen klar forstaelse af bestemte forhold med. Da viden er noget, som de færreste vil afvise som et gode, er det af strategisk betydning i den politiske debat at alliere sig med videnssamfundet. Her er det både interessant og nødvendigt at overveje, hvad det er for forestillinger, der gør sig gældende, og dermed hvilke politiske dagsordener, der sættes, fordi vi er en del af dem på godt og ondt og har en interesse i også at kunne præge dem.

Det bør være en udfordring for filosofien at overveje hvilken form for viden, vi taler om i forhold til videnssamfundet; ikke blot for den filosofiske diskussion, men som bidrag til den offentlige debat. Det er det, der er sigtet med det følgende, som ikke er en original analyse af videnssamfundet, men en

[SLAGMARK 52/2008 · p. 125-135] 
problematisering af, om ikke vores politiske brug af dette navn bærer præg af en alt for snæver opfattelse af viden, nemlig at det er en viden, som er bundet til en vidensøkonomi båret af den produktion, der følger af nye tekniske landvindinger. Efterlyses skal, om ikke en viden om vores ønsker og mål også skulle være indeholdt i videnssamfundet og dermed de former for viden, der hører humaniora og samfundsvidenskaberne til.

\section{En lille forhistorie}

Umiddelbart kan man sige, at videnssamfund ikke er noget nyt. Det vil være rimeligt at sige, at $\mathrm{fx}$ det gamle, israelske samfund var et videnssamfund, da det var ledet af dem, der var kyndige i den religiøs-lovmæssige toraviden. Og det gamle ægyptiske samfund, hvor det var de kyndige i den religiøs-astronomiske og agrare viden (se Stehr 2001, 11). Arten af viden er forskellig, og den religiøse viden i eksemplerne ville ikke kunne kvalificere sig til dagens videnssamfund. Dermed er sagt, at der gennem tiderne har været mange forestillinger om, at samfundet blev 'regeret af viden', og det er nyttigt at se på, hvilken forestilling om viden, vi i dag gør os. Jeg vil ikke bruge det som anledning til at diskutere forskellige tiders former for videnssamfund, kun komme med et par enkelte bemærkninger, som peger på, at en afgørende ingrediens for vores moderne tids opfattelse bliver adgangen til viden. Et moderne videnssamfund synes at være et samfund, hvor viden er sikret bredt distribueret.

Et tidligt eksempel på dette er Tommaso Campanellas Solstaden fra 1602 (se Campanella 2002). Hvad enten Campanellas Poetiske dialog, som undertitlen lyder, er et utopisk ideal eller et realistisk program, er den ikke mere vidtløftig, end den deler senere tiders bestræbelser på at sikre alle en skolegang. Campanellas program for undervisning kunne lyde som noget, der ville begejstre en del politikere af $i$ dag, idet skolegangen skulle begynde tidligt $-i$ treårs-alderen - og der blev lagt stor vægt på, at børnene, fra de var syv år, skulle lære noget om naturen. Mindre begejstret tilslutning må nok forventes til indholdet af denne naturlærdom, idet den hang sammen med metafysik, teologi og astrologi. Opfattelsen af natur ændrer sig lige som opfattelsen af viden, men fra Campanella til os går et fælles ønske om udbredelsen af viden, som det ikke mindst kommer til udtryk i betegnelsen 'oplysningstiden'. Hvilken viden, det så drejer sig om, er igen et andet spørgsmål.

Vores videnssamfund i dag kan således ligne en indfrielse af idealer om at udbrede viden. Viden sikrer, at vi kan magte tilværelsen, og i den forstand er viden magt; scientia est potentia, som det vanligt siges med Campanellas samtidige Francis Bacon. Sagen bliver den, at vi skal kende til vores situation, og kende til vores muligheder, for at kunne gribe ind i den. Viden hænger sam- 
men med at opfatte, hvorledes noget er beskaffent og at kunne omgås det; vi demonstrerer vores viden ved at håndtere tingene og ved at gribe ind i dem på en tilsigtet måde. Viden giver os muligheder for at tilrettelægge noget i modsætning til blot at gøre, hvad vi altid har gjort, uden at være klar over hvorfor. Viden giver et spillerum for handlinger.

En opfattelse af viden, som drejer sig om at magte vores tilværelse ved at kunne tage hånd om den og forme den, har bragt begrebet om viden $i$ en bestemt retning. Det handler da om viden, der sikrer vores materielle vilkår, altså om praktiske forhold, om vores konkrete erfaringer og evne til at fremstille noget, der løser problemer. En sådan viden er en anden end den, der søgtes som svar på tilværelsens forhold ved at have viden om de religiøse skrifter og fortællinger. For en naiv betragtning er der tale om, at de religiøse forklaringer forsvinder $i$ takt med, at vi får en mere nyttig viden om verden. For den mere reflekterede er der tale om, at vi får andre forventninger til hvilken slags viden, der giver svar på vores spørgsmål. Vi kommer til at stille andre spørgsmål og stiller os tilfreds med andre typer af svar. Fælles er, at vi gerne vil handle fornuftigt, hvilket vil sige at kunne forlade os på de sammenhænge, vores handlinger griber ind $\mathrm{i}, \mathrm{og}$ at kunne forlade os på de forandringer, vi fremkalder. Vi skal kende til den virkelighed, vi handler i, og vi skal kunne overskue konsekvenserne af det, vi gør (se Lübbe 1983, 92).

Vi opfatter altså viden forskelligt, ikke bare til forskellige tider, men også i forhold til vores aktuelle diskussioner. Vi taler om viden for at kunne noget, og viden for at kunne det, vi skal. Uden viden har vi ikke de ønskede muligheder for $\mathrm{fx}$ at gribe ind i natur og mennesker; men viden om, hvordan det kan gøres, er ikke også viden om, hvorvidt det bør eller skal gøres. Vi må på den ene side kende til de midler, der må stå til rådighed for at kunne magte vores tilværelse, det vil sige det instrumentelle. Vi må også have viden om vores tilværelse, og hvad det er for ønsker, der får os til at ville magte den sådan, som vi vælger at gøre. Det vil sige, at vi må have viden om målene. Den instrumentelle viden har altid været vigtig som den viden, vi må have for at overleve. Men lige så vigtig er viden om mål, altså den viden der gør vores praktiske liv meningsfyldt.

\section{På udkig efter videnssamfundet}

Til en diskussion af videnssamfundet vil det være nyttigt kort at kaste et blik på, hvad det egentlig er, der aktuelt optræder under overskriften videnssamfundet. En ingrediens i videnssamfundet er internettet. Et hurtigt besøg på Google giver med søgning på 'videnssamfund' henholdsvis 'kunskapssamhället', 'knowledge society' og 'Wissensgesellschaft' en uoverskuelig mængde hits 
(i maj 2008 sammenlagt omkring halvanden million, men det svinger meget, således gav det februar 2007 sammenlagt 2,8 millioner hits). Det er selvsagt et antal resultater, der ikke lige er til at kigge igennem. Da det i forvejen er problematisk som empiri, må det være tilladt at fortsætte i det lidt problematiske spor og blot kigge på de første resultater. Her bemærkes det, at $\mathrm{i}$ alt overvejende grad forstås videnssamfundet i forhold til højteknologi ( $\mathrm{fx}$ bio- og nanoteknologi) samt IT og kommunikation. I lidt mindre grad melder energi og jordbrug sig. Et andet helt dominerende forhold er, at det hænger sammen med økonomi - $\mathrm{i}$ videnssamfundet har vi en vidensøkonomi! Viden og ideer hænger sammen med vækst - på dansk hedder det bl.a. 'viden i vækst' og 'fra forskning til faktura'. Kort drejer det sig om, at værdiskabelsen ikke ligger $i$ at producere varer, men $i$ at have ideer og viden, der er penge værd som patenter, copyright, varemærker etc. Hvis viden giver handlemuligheder, da betyder distribueringen af viden sammen med den store vækst $i$ adgangen til informationer i de foregående årtier en stærk forøgelse af muligheder, der er mere værd netop som muligheder end som realiserede varer. Som Jeremy Rifkin (2001) peger på, er det ikke det at eje noget, der tæller, men det at have adgang til noget.

Ser man på de danske hits, så er der få resultater fra fx humanistisk side, hvor der peges på et noget bredere begreb om viden. I overraskende ringe grad forbindes videnssamfundet med oplevelsesøkonomi og kreative fag, selv om kreativitet og innovation ellers er hyppige gæster på resultaterne, men så hænger det sammen med ny viden i forhold til medicin, IT etc. Ser man på de engelske og tyske resultater, så er der også et udvalg af samfundsvidenskabelige diskussioner; noget tilsvarende på svensk hvor det også drejer sig om kunst og kultur, om uddannelse, og om at tackle et forandret arbejdsmarked og de strukturelle forandringer, der sker i samfundet.

Det er altså ikke så entydigt, hvad det egentlig er, der menes med videnssamfundet. Det omfatter viden om noget bestemt, fx det højteknologiske. Der er tilsyneladende i nogle sammenhænge også blik for, at det har med målene for vores samfund at gøre. I alt overvejende grad er det dog det første.

Det synes klart, at der er to vigtige ingredienser i videnssamfundet:

- Det er et samfund, hvor viden er i højsæde - en viden der skal sikre vores materielle vilkår og udvikle dem.

- Det er et samfund, hvor viden er (økonomisk) værdiskabende.

Det sidste er afgørende. For virkelig at være et videnssamfund skal der også være en vidensøkonomi. Jeg vil dog først vende opmærksomheden mod det første. Som antydet før, så er det næppe mængden af specialiseret viden i sig 
selv, der gør det ud for et videnssamfund, selv om det ofte ser ud til at være det, der er meningen, når der tales om videnssamfundet. Det er snarere den betydning, viden får, fordi den tjener til at indfri de ønsker, vi har - ønsker, der i høj grad hænger sammen med de materielle vilkår. Dermed hænger det også sammen med økonomien. At prioritere og afsætte midler til det, vi vil, gør noget værdifuldt. Men viden som sådan gør ingen forskel, hvis ikke vi vil noget med den.

\section{Ekspertviden og offentlighed}

Det er vigtigt at understrege, at der er forskel på at kende til de midler, vi har brug for, for at kunne magte vores tilværelse, og så det at vide hvad vi har brug for - hvad vi vil. Det er her værd at mindes Rousseau og hans svar på spørgsmålet, om viden har ført til en forbedring af sæderne (Rousseau [1750] 1983). Hans svar er som bekendt, at det ikke er tilfældet. Genoprettelsen af videnskaberne og kunsterne har ikke ført til en forbedring af sæderne, for det er ikke det samme at have viden, hvormed vi kan gøre noget, og så at vide, hvad vi vil gøre. Og det er svaret på det sidste, der afgør, om vores viden også bringer os noget godt.

At vide, hvad vi vil, kunne godt lyde som et problem i dag. Distributionen af viden har jo samtidig svækket traditionelle orienteringsrammers autoritet såvel som samfundets institutioner og magthierarkier. Den brede distribution af viden har skabt en selvbevidst offentlighed, som kræver tilfredsstillende forklaringer, og som stiller med mangeartede forventninger i forhold til, hvornår forklaringer er gode nok. Kants ord om oplysningen som det at have mod til at bruge sin forstand (Kant 1987, 82) rummer den konsekvens, at den offentlige mening bliver mangfoldig, hvad angår hvilke orienteringsrammer, der anerkendes. Oven i det kommer også, at det moderne samfund synes kendetegnet ved en kompleksitetsforøgelse som resultat af en stadig større grad af differentiering og specialisering på og i forskellige områder. En stadig mere specialiseret viden synes nødvendig for at kunne begå sig på de områder, man bliver involveret i, og overblikket over samfundets udvikling stadig vanskeligere at få.

Om der kan tales om en orienteringskrise hænger nok sammen med, hvad vi forventer af viden og mål. For det meste ved vi nok godt, hvad vi vil. Vi vil sikre vores materielle velfærd, sociale sikkerhed og personlige frihed. Problemet er ikke, om vi vil dét; problemet er, hvordan vi vil det, og hvordan vi vil tilrettelægge og prioritere vores midler. Sagen er, at vi har fået sværere ved at sige, hvad vi skal gøre, for at opnå det, som vi vil. Det kræver eksperthjælp. Vi har altså brug for specialiseret viden, men for at den spiller en rolle, skal den 
forbindes med vores praksis. Eksperthjælp og specialviden er som sådan ikke så meget bevendt, hvis ikke den også kan passes sammen med vores konkrete forståelse og praksis - hvis ikke den kan få kulturel og social betydning (se Lübbe 1983, 87 ff.).

Fristelsen til at sige, at ophobningen af viden bliver et videnssamfund, er en misforståelse - eller det er i hvert fald et alt for fattigt perspektiv. Vi skal kunne forbinde de informationer, vi modtager, med den virkelighed, vi lever $i$, ved at vise hvor og hvordan informationerne er passende. Kendskabet til en masse informationer er et meget snævert perspektiv på viden; en sådan ophobning af specialviden er den, man kender fra nørden, det vil sige den, der ved en masse om noget bestemt, men ikke samtidig udviser de bedste sociale færdigheder. Det betyder ikke, at der er noget galt med den ekspertviden; den er nødvendig for at få de muligheder, vi ønsker. Det betyder blot, at vi må vide noget andet, end denne ekspertviden selv kan indeholde.

Det er altså ikke ekspertviden som sådan, der er det interessante, men hvad vi vil med den, og hvordan den bliver taget $i$ anvendelse, så vi får de ønskede handlemuligheder. Der er brug for et fokus på, hvorledes vi integrerer viden $\mathrm{i}$ vores erfaringer. Her er det, at et fokus på videnssamfundet, der blot drejer sig om adgangen til og distributionen af viden, som egentlig blot er informationer, er utilstrækkeligt til at karakterisere vores samfund som et videnssamfund. Det er stadig et informationssamfund. Skal vi tale om videnssamfundet, da er der grund til at forbinde det med andet og mere end mængden af tilgængelige informationer.

Det er da værd at bemærke andre af de aktuelle karakteristikker af vores tid, nemlig at det også handler om en viden, der fortælles, så viden kan integreres $\mathrm{i}$ de forskellige livssammenhænge. Også fortælling er på den aktuelle dagsorden med det lidet danskklingende navn story-telling; og selv om det da drejer sig om fortællinger med kommercielle motiver, så afslører det noget om vores forventninger: Vi er modtagelige for en anden form for begrundelse end den, der lægger sin hovedvægt på formidlingen af en række fakta. Det kan pege på, at måderne, hvorpå vi gør viden anvendt, må regnes med til det, et videnssamfund drejer sig om. Et videnssamfund handler ikke kun om højteknologi og IT, men også om den kulturelle og sociale betydning og anvendelse af viden. Det handler ikke kun om dannelsen af databaser og højteknologiske satsningsområder, men om dannelsen af de mennesker, der lever i videnssamfundet. 


\section{Viden som vardiskabende}

For at der kan tales om et videnssamfund, måtte der også være en vidensøkonomi. Det er ikke nok, at viden spiller en vigtig rolle, som det jo altid har været tilfældet. Det er omfanget af den værdiskabelse, der skyldes viden, der gør det til et videnssamfund. Afgørende bliver det at have adgang til noget, ikke at eje det. Som nævnt peger Jeremy Rifkin i The Age of Access (2001) på, at virksomheder ofte ikke ejer så meget, men køber adgang til forskelligt udstyr og tilhørende service. Der er ingen grund til at eje kopimaskinerne, computerne etc., det er bedre at lease dem, og baggrunden for at kunne gøre det er at være et godt brand og have brugsretten til den nødvendige viden (se Rifkin 2001, 40 ff., 73 ff.). Noget tilsvarende gælder også i et stort omfang for vores private forbrug. Det kan godt være, at vi taler om, at det er vigtigt at eje sin bolig m.m., men i realiteten drejer det sig jo for det meste om et langtidsarrangement med bank, kreditforening etc.

Det hedder, at i videnssamfundet er det viden, der skaber værdi og vækst. Forestillingen om, hvilken viden, kan dog forekomme betænkelig snæver, når det i så høj grad bliver kædet sammen med IT og med forskning i det satsningsområde, som varetages af højteknologifonden. For at citere statsministeren: "[...] forskere og universiteter skal opmuntres til at søge patenter på deres gode idéer, så de ikke blot forsvinder blandt kolberne i laboratoriet" (Rasmussen 2005). Så fik vi også lige på plads, hvad det er for en viden, det drejer sig om!

Det skal ikke bestrides, at der er penge i den forskning, der stammer fra laboratoriernes kolber eller fra nye tekniske muligheder i forhold til kommunikation. Selv om udvidelsen af kommunikationsmulighederne ikke nødvendigvis er fulgt op af, at der er mere at kommunikere - hverken af interessant indhold eller af nyheder - så må man holde sig for øje, at værdiskabelse ikke behøver at betyde, at det gamle udgør målestokken for værdien af det nye. Nye muligheder uden nyt indhold kan være medvirkende til, at behov ændres og giver nye områder værdi, uanset om de kan måles med det gamles forventninger. Man kan tvivle på, at der er interessante nyheder nok til en nyhedskanal i døgndrift i Danmark, men man bør her fokusere på, at nyheder i døgndrift er med til at ændre på nyhedsbilledet og vores vaner, og dermed på at noget andet værdsættes, end der gjaldt forhen. Det peger så også på, at værdiskabelse kræver en opmærksomhed, der ikke er tilstrækkeligt belyst ved blot at henvise til, at der kommer produktion og øget omsætning ud af produkterne fra laboratorier og kommunikationsteknologi.

Igen må man tænke, at en ophobning af viden i sig selv ikke gør det ud for et videnssamfund, og en sådan ophobning bør også kun betragtes som en ophobning af informationer. Men ophobningen af informationer kan let 
forblænde; det giver os en falsk tro på, at vi har fået viden, og at den viden uden forbehold er nyttig og værdifuld. Selv om det på nogle områder kan give en økonomisk værdiforøgelse, så kan det også have omkostninger, der ikke regnes med. Der er en risiko for, at en forøget informationsmængde også betyder, at vi bliver mere og mere ligeglade med dem. Der kan tales om en implosion af mening, som Jean Baudrillard gør det, fordi forøgelsen af mængden af informationer ikke er en udvidelse af meningsfulde informationer, men en hastig devaluering af betydningen af dem (se Baudrillard 1994, 79 ff.). Vi har svært ved at blive berørt af dem eller se deres betydning for os, fordi langt størsteparten af dem kun har en marginal berøring med vores konkrete liv (se Lübbe 1983, 63 ff.).

Vokser mængden af informationer, vokser som nævnt også behovet for eksperthjxlp. Eller det kan siges omvendt: Vores mulighed for selv at tackle informationerne mindskes og en hjælpeløshed indtræder. Den afhjælper vi netop ved at søge eksperthjælp, men selv om vi anerkender den hjælp, og er afhængige af den, så synes den også i fare for at tømmes for sin kulturelle betydning. I takt med at den vokser i betydning som forudsætningen for vores livsgrundlag, vender vi den ryggen som værende interessant (se Lübbe 1983, 122).

Der synes altså at ske det, at $\mathrm{i}$ takt med forøgelsen af den form for viden, der er nødvendig for at sikre vores materielle velstand og livsgrundlag i en moderne, teknisk kultur, så formindskes dens betydning som kulturelt gældende. Igen skal det understreges, at det ikke er for at underkende, at nyt teknisk apparatur har en enorm betydning for vores adfærd, og hvad vi investerer vores penge i, tænk blot på hvor meget mobiltelefonen har påvirket vores vaner $\mathrm{i}$ de seneste år. Men pointen er at sige, at et videnssamfund, der skal gøre sig fortjent til det navn, må betyde mere end blot forøgelsen af den tekniske viden. Det må dreje sig om at vide, hvad den viden gør ved os. Vi kommer til at ville noget andet; til at se anderledes på vores omgivelser og til at værdsætte dem på andre måder.

Så selv om den form for viden, der hører til højteknologi og informationsteknologi, umiddelbart er økonomisk værdifuld, så er det interessante at få viden om, hvordan den bliver samfundsmæssigt gældende. Det sker selvfølgelig $i$ et eller andet omfang, når patenter bliver til produktion, men hvis det mest af alt kun er det, videnssamfundet betyder, så er vi ikke kommet et skridt videre fra industrisamfundet. Vi har blot forøget specialiseringsgraden. Kigger man bredere end på den hjemlige, politiske dagsorden, så er der også tale om, at der ses på fx design, ledelse, uddannelse, markedsføring etc. Da kommer også andre former for viden på spil, der er anderledes rettet mod virkeligheden $\mathrm{i}$ dens konkrete virke. Et videnssamfund kommer da mindre til at dreje sig om 
at producere 'videnstunge' produkter og mere om forskellige serviceydelser. Det er dér, at den egentlige vidensøkonomi befinder sig.

Der synes at være en parallel at trække mellem vidensøkonomien og 'human kapital', som den amerikanske økonom Gary S. Becker introducerede i 1960'erne (se Becker 1964). Pointen var at se på den enkeltes uddannelse og erhvervserfaring som en del at den enkeltes evner og dermed at forklare arbejde som en produktivkraft. En vidensarbejder er ingen statisk størrelse, men udvikler sig og kan ikke uden videre udskiftes med en anden, som det er tilfældet med mekanisk arbejde.

Jeg vil ikke gå ind på diskussionen om human kapital, men med inspiration fra Mario Perniola pege på, at i vidensøkonomien bliver viden som produktivkraft uregerlig (se Perniola 2002, 131 f.). Det bliver vigtigt at flytte fokus fra producenten og viden over til de sammenhænge, de begår sig i - altså til forbrugerne og offentligheden. Det bliver netop forbindelsen mellem den viden, vi får, og de ønsker, vi har, der trænger sig på - altså at omsætte viden til handlinger $\mathrm{i}$ en virkelighed vi kender, og med konsekvenser vi kan overskue. Der, hvor det brænder på $\mathrm{i}$ et videnssamfund, synes at være, hvor der skabes en interesse og opmærksomhed i offentligheden, så den vil noget bestemt. Derfor drejer videnssamfund og -økonomi sig ikke så meget om højteknologi som om oplevelser og opmærksomhed - og vi taler jo netop også om oplevelsesøkonomi og opmærksomhedsøkonomi (se Pine \& Gilmore 1999; Franck 1998).

Det værdiskabende er ikke så meget udviklingen af en ny kombineret mobiltelefon og pc med udfoldelig, papirstynd skærm, nanorobotten som afløser for kirurgen eller den multiresistente byg, som det er skabelsen af behov og løsningen af serviceopgaver. Der er ingen tvivl om det højteknologiskes værdi, ganske enkelt fordi det er blevet en afgørende del af vores materielle eksistensgrundlag. Men det er samtidig gået hen og er blevet noget, vi tager for givet som en forøgelse af vores produktion og tekniske muligheder. Der skal såmænd nok være en efterspørgsel på det, men værdiforøgelsen ligger i højere grad ved den fascinationskraft, noget har. Vinderen af markedet er ikke det, der blot kan mere end før. Vinderen er det, der kan give os indtryk af, at vi kan noget mere med vores liv.

\section{$V$. Viden og videnssamfundet}

For at sammenfatte det foregående, så er det min pointe at sige, at videnssamfundet ikke kun bør dreje sig om forøgelsen af mængden af specialviden, hvilket ligger bag størstedelen af den hjemlige diskussion af videnssamfundet. Dette er ganske vist forudsætningen for vores moderne samfund og lægger sig 
i forlængelse af de ønsker, vi har haft gennem de seneste århundreder, om at kunne sikre vores livsvilkår på den bedst mulige måde. Men dette udgør ikke et videnssamfund. Det er blot et informationssamfund eller industrisamfund med ekstra tekniske virkemidler.

Et videnssamfund må, hvis det skal give mening at tale om det, rumme andre former for viden, nemlig en viden om, hvad vi vil med vores hjælpemidler. Det handler om service og kultur - om at vi ikke kun ser på vores instrumenter, der skal sikre livet, men om at finde ud af, hvordan vi vil leve. Derfor er det også interessant at bemærke, at værdier i et videnssamfund i høj grad er forbundet med oplevelser. Et videnssamfund synes også at hænge sammen med en oplevelsesøkonomi. Umiddelbart kunne det lyde ejendommeligt, for viden og oplevelser er almindeligvis ikke så nært beslægtet; men sagen er vel, at den viden, der har sikret os et basalt mål af materiel velstand, netop har sikret den så godt, at vi tager den for givet og får overskud til at bekymre os om, hvad vi vil med den, og hvordan vi vil bruge den. Et videnssamfund hænger ikke kun sammen med at udbygge den velstand, vi har. Det hænger også sammen med at diskutere, hvordan vi vil indrette os, så vi lever godt. Det handler ikke kun om velstand, men også om velfærd, altså ikke kun om båndbredde, GPS-styring i bilen og produktionsforøgelse, men om, hvad vi vil med det, og hvad det gør ved os.

Skal vi tale om et videnssamfund, så bliver det vigtigt, at det drejer sig om, at nogle vilkår har ændret sig, så det ikke blot er et industrisamfund, hvori der sker en vækst i nogle videnstunge erhverv. Det drejer sig om, at ønsket om at erhverve og distribuere den viden, der sikrer vores eksistens og giver plads til at udfolde os, som vi ønsker, også har betydning for, hvordan vi ser på os selv, og hvordan vi lever. Selv om vi overordnet ved, hvad vi vil, nemlig leve godt, trygt og længe, så har vi også brug for at diskutere, hvad godt og trygt betyder. Distributionen af viden skulle ikke kun sikre, at vi får så mange teknikere som muligt, men også at vi får en offentlighed, der værner om sine politiske opgaver. De tekniske muligheder for kommunikation og adgang til at finde viden fører jo ikke af sig selv til en kritisk og selvtænkende offentlighed. Det kan i lige så høj grad ende med, at informationerne bliver ligegyldige, og at massemediernes kommunikation bliver et forum for selvsving og tomgang, der nivellerer alle betydningsforskelle.

Der er andre former for viden end den instrumentelle; det er også nødvendigt at vide, hvornår og i hvilket omfang man skal bruge de forhåndenværende instrumenter, ligesom det er nødvendigt at vide, hvad brugen af dem gør ved os. Hvis ikke videnssamfundet også kommer til at rumme viden om sociale og kulturelle forhold, så er det ikke interessant, for så er det blot et tomt navn for det industri- og informationssamfund, vi allerede har. Det er betænkeligt, 
fordi det præger synet på os selv og vores omgivelser på måder, der ikke levner plads til eftertanke - altså plads til at tænke over om vores behov for at orientere os i en moderne, højteknologisk kultur besvares ved mobiltelefoner med GPS-udstyr, eller om det snarere hænger sammen med viden om ændringer i vores sociale behov og normer. Industrisamfundet havde vismænd, nemlig de økonomiske. Måske videnssamfundet også har brug sine vismænd, nemlig nogle, der ved noget om mennesker ud over noget om de menneskelige gener!

\section{Litteratur}

Baudrillard, Jean: ([1981] 1994) Simulacra and Simulation oversat af. S.F. Glaser, USA.

Becker, Gary S.: (1964) Human Capital: A Theoretical and Empirical Analysis, with Special Reference to Education, Chicago.

Campanella, Tommasso: ([1602] 2002) Solstaden, oversat af. O. Jorn, Frederiksberg.

Franck, Georg: (1998) Ökonomie der Aufmerksamkeit, München/Wien.

Kant, Immanuel: ([1784] 1987) "Besvarelse af spørgsmålet: Hvad er oplysning?", oversat af. K. Jensen, in: Slagmark, nr. 9, Århus, 82-88.

Lübbe, Hermann: (1983) Zeit-Verbältnisse. Zur Kulturphilosophie des Fortschritts, Graz/Wien/ Köln.

Perniola, Mario: (2002) "Cultural turning points in art. Art between parasitism and admiration”, in: Res 41, 127-135.

Pine, J. \& Gilmore, J.: (1999) The Experience Economy, Boston.

Rifkin, Jeremy: (2001) The Age of Access. The New Culture of Hypercapitalism Where All of Life Is a Paid-for Experience, New York.

Rasmussen, Anders Fogh: (2005) Redegørelse i Folketinget 24. februar 2005,

www.stm.dk $/$ Index $/$ dokumenter.asp?o $=2 \& n=0 \& h=2 \& \mathrm{t}=14 \& d=2265 \& \mathrm{~s}=1 \& \mathrm{str}=$ stor (maj 2008).

Rousseau, Jean-Jacques: (1983) Schriften zur Kulturkritik (Die zwei Diskurse von 1750 und 1755) ed. K. Weigang, Hamburg.

Schulze, Gerhard: (1992) Die Erlebnisgesellschaft. Kultursoziologie der Gegenwart, Frankfurt a.M./ New York.

Stehr, Nico: (2001) "Moderne Wissensgesellschaften“, in: Aus Politik, und Zeitgeschichte B36, 7-13. 